\title{
Fiatal felnőtt korban diagnosztizált familiáris mediterrán láz
}

\author{
Poset Henrietta $^{1, @}$, Kárteszi Judit ${ }^{2}$, Kalmár Tibor ${ }^{3}$, Maróti Zoltán ${ }^{3}$, \\ Fekete Julianna ${ }^{4}$, Egyed Miklós ${ }^{1}$ \\ ${ }^{1}$ Somogy Megyei Kaposi Mór Oktató Kórház, Hematológiai Osztály, Kaposvár \\ ${ }^{2}$ Zala megyei Szent Rafael Kórház, Genetikai Tanácsadás, Zalaegerszeg \\ ${ }^{3}$ SZTE Szent-Györgyi Albert Klinikai központ, \\ Gyermekgyógyászati Klinika és Gyermek Egészségügyi Központ, \\ Genetikai Diagnosztikai Laboratórium, Szeged \\ ${ }^{49}$. sz. Felnőtt Háziorvosi Szolgálat, Kaposvár
}

\begin{abstract}
A familiáris mediterrán láz a herediter autoinflammatorikus betegségek közé tartozik. Klinikai tüneteit döntően a savós hártyák akut gyulladása (serositis: peritonitis, pleuritis, synovitis, ritkán pericarditis, meningitis) határozza meg. A betegség hátterében a pyrin fehérjét kódoló MEFV-gén többségében autoszómális recesszív módon öröklődő mutációi állnak. Legfontosabb szövődménye az amyloidosis, amely veseelégtelenséghez vezethet. Kezelésében első vonalbeli terápiaként a colchicin szerepel.

Fiatal nőbetegünket 12 éves kora óta több intézetben vizsgálták intenzív hasi fájdalommal és lázzal járó attakok miatt. A tünettan részeként hányás, hasmenés és mellkasi fájdalom jelentkezett. A gyulladásos epizódok 5-14 napig tartottak, a köztes időszakokban viszont teljesen jól volt. A rohamok alatt készült laboratóriumi vizsgálatok során leukocitózis, valamint emelkedett süllyedés és CRP mutatkozott. Intravazális hemolízisre utalt az anémia, retikulocitózis, magas Sebi, szérum szabad hemoglobin és LDH együttes megjelenése. Az EKG-én inferior és az anteroseptalis elvezetésekben átmenetileg negatív T-hullámok jelentek meg, ami pericarditis lehetőségét vetette fel. Fizikális státuszából kiemelendő a diszkrét, de progrediáló splenomegalia. Kizártuk a porphyriat, glucose-6-phosphat dehydrogenase-hiányt, PNH-t és C1-inhibitorhiányt. Az autoinflammatorikus betegség miatt elvégzett molekuláris genetikai vizsgálat az MEFV-génmutáció homozigóta formáját, a Familiáris mediterrán láz diagnózisát igazolta.
\end{abstract}

Kulcsszavak: autoinflammatorikus, serositis, MEFV-gén, hasi fájdalom, láz, amyloidozis, intravazális hemolízis

\section{Familial Mediterranean fever diagnosed in early adulthood}

The familial Mediterranean fever is one of the hereditary autoinflammatory diseases. Its clinical symptoms are mainly determined by acute inflammation of the serous membranes (serositis: peritonitis, pleurisy, synovitis, rarely, pericarditis, meningitis). The background of the disease is mostly represented by autosomal recessively inherited mutations in the MEFV gene encoding the pyrine protein. Its most important complication is amyloidosis, which can lead to renal failure. Colchicine is included in its treatment, as a first-line therapy.

Our young female patient has been examined in several institutions since the age of 12 for attacks of intense abdominal pain and fever. The symptoms included vomiting, diarrhea, and chest pain. The inflammatory episodes lasted 5-14 days, but in the intervening periods she was free of symptoms. Laboratory tests performed during the inflammatory periods showed leukocytosis as well as increased ESR and CRP. Intravascular hemolysis was indicated by anemia, reticulocytosis, co-occurrence of high Sebi, serum free hemoglobin and LDH. On the ECG, transiently negative T waves appeared in the inferior and anteroseptal leads, raising the possibility of pericarditis. Of her clinical status, discrete but progressive splenomegaly should be highlighted. Porphyria, glucose-6-phosphat dehydrogenase deficiency, $\mathrm{PNH}$, and $\mathrm{C} 1$ inhibitor deficiency were excluded during our examinations. Molecular genetic testing urged by autoinflammatory disease confirmed a homozygous form of the MEFV gene mutation and established the diagnosis of familial Mediterranean fever.

Keywords: autoinflammatory, serositis, MEFV gene, abdominal pain, fever, amyloidosis, intravascular hemolysis

(Beérkezett: 2020. október 1.; elfogadva: 2020. november 25.)

\footnotetext{
@ Levelezési cím: Dr. Poset Henrietta, Kaposvár 7400, Tallián Gyula u. 20-32., E-mail: possethhenriett@yahoo.com, Tel.: +36-82/501-300
} 


\section{Rövidítések}

IVF - in vitro fertilizáció; LDH - laktát dehidrogenáz; $\mathrm{MCH}$ mean corpuscular hemoglobin; MCV - mean corpuscular volumen; MEFV - Mediterranean fever gene; $\mathrm{PNH}$ - paroxysmalis nocturnalis hemoglobinuria

\section{Esetismertetés}

Huszonnyolc éves mediterrán lázas nőbeteg kórtörténetét ismertetjük. A 19-28 éves kora közötti 10 évben több intézetben végzett klinikai vizsgálatokat kronológiai sorrendben mutatjuk be.
Családi anamnéziséből kiemeljük, hogy édesanyját kappa könnyúlánc myeloma multiplex miatt kezeljük. Betegünk IVF várandósságból (spermium donáció) született. Tizenkét éves kora óta jelentkeztek időszakosan rohamszerű nagyon erős, görcsös hasi panaszai, melyet láz, hányás és hasmenés kísért. Az 5-14 napig tartó rohamok alatt- vizelete sötétebb lett és bokái körül hideg környezetben apró vöröses hólyagok jelentek meg. Ízületi panasza nem volt. Egy kifejezett jobb oldali hasi görcsös fájdalma miatt appendectomián is átesett. Gyógyszert rendszeresen nem szedett, alkoholt és drogokat egyáltalán nem fogyasztott, és nem is dohányzott.

1. táblázat. Hematológiai kivizsgálása során észlelt laboratóriumi eredmények

\begin{tabular}{lcccc}
\hline Analízis & Egység & Referenciatartomány & 2018.04 .20$. & 2018.04.23. \\
\hline Abszolút neutrofilszám & $\mathrm{G} / 1$ & $2,00-8,50$ & 13,86 & 4,00 \\
Abszolút limfocitaszám & $\mathrm{G} / 1$ & $1,00-5,00$ & 1,21 & 1,28 \\
Abszolút monocitaszám & $\mathrm{G} / 1$ & $0,01-1,00$ & 1,08 & 0,58 \\
Abszolút eozinofilszám & $\mathrm{G} / 1$ & $0,00-0,50$ & 0,01 & 0,03 \\
Abszolút bazofilszám & $\mathrm{G} / 1$ & $0,00-0,50$ & 0,02 & 0,03 \\
Trombocitaszám & $\mathrm{G} / 1$ & $100-450$ & 243 & 231 \\
Hemoglobin & $\mathrm{g} / 1$ & $125-155$ & 147 & 126 \\
Vörösvérsejtszám & $\mathrm{T} / 1$ & $4,10-5,10$ & 5,03 & 4,31 \\
MCV & $\mathrm{fl}$ & $80,0-96,0$ & 84,1 & 84,9 \\
MCH & $\mathrm{pg}$ & $28-35$ & 29 & 29 \\
LDH & $\mathrm{U} / 1$ & $240-480$ & 903 & 444 \\
Serum bilirubin & $\mathrm{umol} / 1$ & $5-20$ & 46 & 11 \\
Direkt bilirubin & $\mathrm{umol} / 1$ & & 9,9 & \\
Retikulocyta & $\mathrm{G} / 1$ & $30-100$ & 38 & 180 \\
\hline
\end{tabular}

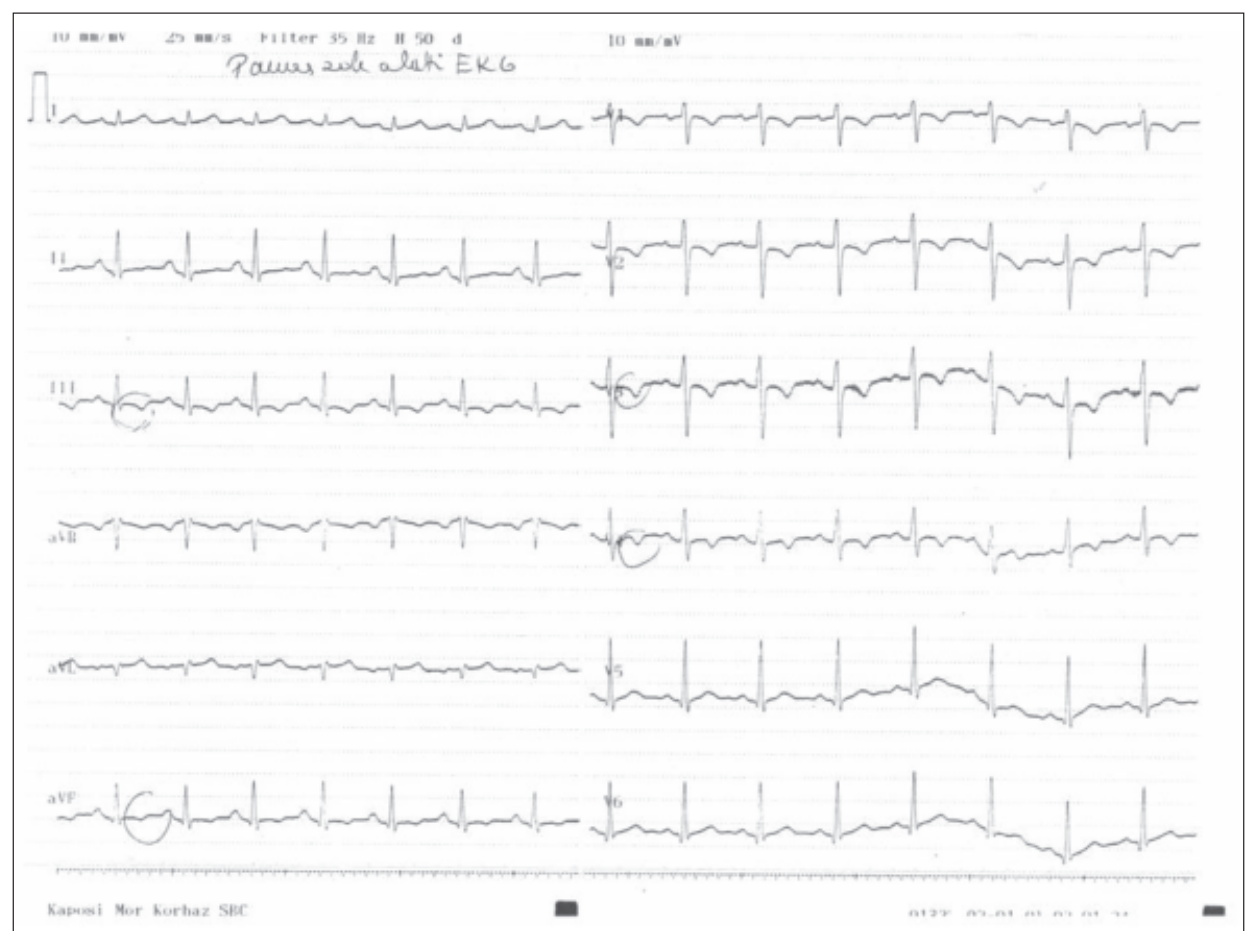

1. ábra. EKG roham alatt. Az inferior és az anetroseptalis elvezetésekben átmenetileg negatív T-hullámok jelentek meg 
19 évesen: egyiptomi nyaralást követően jelentkező alhasi görcsös fájdalmak, hasmenés és hányás miatt, infektológiai, nőgyógyászati és gasztroenterológiai vizsgálata is negatív eredményt igazolt, parazitás fertőzést kizártak. Laboreredményeiből emelkedett gyulladásos paraméterek (fvs: $19000 \mathrm{G} / \mathrm{l}, \mathrm{CRP}: 42 \mathrm{mg} / \mathrm{l}$ ) emelhető ki. A negatív vizeletvizsgálat és leoltás ellenére akut cystitist véleményeztek és antibiotikum-kezelést kapott. Panaszai megszűntek, majd 3 hónap múlva ismételten jelentkeztek, ekkor vizsgálata során mérsékelt splenomegaliát is észleltek. (A lép alsó pólusa $3 \mathrm{~cm}$-rel meghaladta a bal bordaívet. Laboratóriumi vizsgálatai ismételten magas gyulladásos paramétereket mutattak. A képalkotó vizsgálatok (mellkasröntgen, hasi-UH) a mérsékelt splenomegalián kívül lényeges eltérést nem igazoltak. Széklet és vizelet mikrobiológiai vizsgálata során kórokozó nem tenyészett ki.

21 évesen: palpitációs panaszok miatt echocardiographia készült, kóros eltérést nem találtak. Panaszait vegetatív eredetünek véleményezték.

23 évesen: visszatérő hasi panaszai miatt ismételt gasztroenterológiai kivizsgálás (oesophago-gastro-bulboscopia és colonoscopia) történt, negatív eredménnyel. Laboratóriumi leleteiből a magas We: $58 \mathrm{~mm} / \mathrm{h}, \mathrm{CRP}: 186 \mathrm{mg} / \mathrm{l}$, SeBi: 33 umol/1 és lymphocytopenia $0,8 \mathrm{G} / 1$ emelhető ki. A hasi-CT mérsékelt hepato-splenomegaliat igazolt.

24 évesen: vizsgáltuk először hematológiai ambulanciánkon intravazális haemolízis gyanúja miatt. Laboratóriumi eredményeit az 1 . táblázatban mutatjuk be. A kezdeti leukocytosisa magas LDH és SeBi értéke gyorsan normalizálódott, a csökkenő hemoglobin és szérum szabad hemoglobin mellett kifejezett reticulocytosist észleltünk. IgA-hiány is igazolódott és a vércsoport szerológiai vizs- gálata során ellenanyagot nem mutattunk ki. Porphyriát és PNH-t kizártunk. Hasi UH-on a lép hilusi átmérője $50 \mathrm{~mm}$, hossza $150 \mathrm{~mm}$ volt volt. A gyulladásos periódusban jelentkező mellkasi fájdalom miatt készült EKG-n, pericarditisre jellegzetes elváltozások voltak detektálhatók (1., 2. ábra).

26 évesen: immunológiai és reumatológiai vizsgálatai IgA-hiányon kívül egyéb patológiás eltérést nem találtak.

27 évesen: HIV 1-2, hepatitis B, C, EBV, CMV és SLE irányú immun szerológiai vizsgálatai negatívak voltak és kizártuk a C1-inhibitor-hiányt is. Bár transzfúzióban nem részesült, vércsoport szerológiavizsgálata során pozitív ellenanyagszürés mutatkozott. Vércsoport: $0 \mathrm{Rh} \mathrm{D}$ poz. vvt antigén: $\mathrm{C}+\mathrm{E}+\mathrm{c}+\mathrm{e}+\mathrm{K}$, direct Coombs-pozitív, enzimreaktív antitest. Duodenumbiopszia coeliakiát nem igazolt.

28 évesen: az esetleges favizmus gyanúját a glükóz6-foszfát dehidrogenáz-aktivitás mértéke kizárta. Az autoinflammatorikus gének NGS-vizsgálata 31 gént analizálva az MEFV-gén homozigótamutációját igazolta: c.2080A > G (p.Met694Val), amely a familiáris mediterrán láz klinikai diagnózisát támasztotta alá (3. ábra).

\section{Megbeszélés}

Esetismertetésünkkel a ma már hazánkban is elérhető széles körü genetikai vizsgálatokra szeretnénk felhívni a figyelmet. Az új generációs szekvenálás (NGS: „new generation sequencing”) egyszerre több gén vizsgálatát lehetővé téve megreformálta a genetikai diagnosztikát. A vizsgálat különösen nagy jelentőségű klinikailag hasonló kórképek elkülönítésében, ahol több gén mutációja állhat a háttérben (genetikai heterogenitás). Hosszas, eredménytelen (vagy nem informatív) kivizsgálásokat tud kiváltani

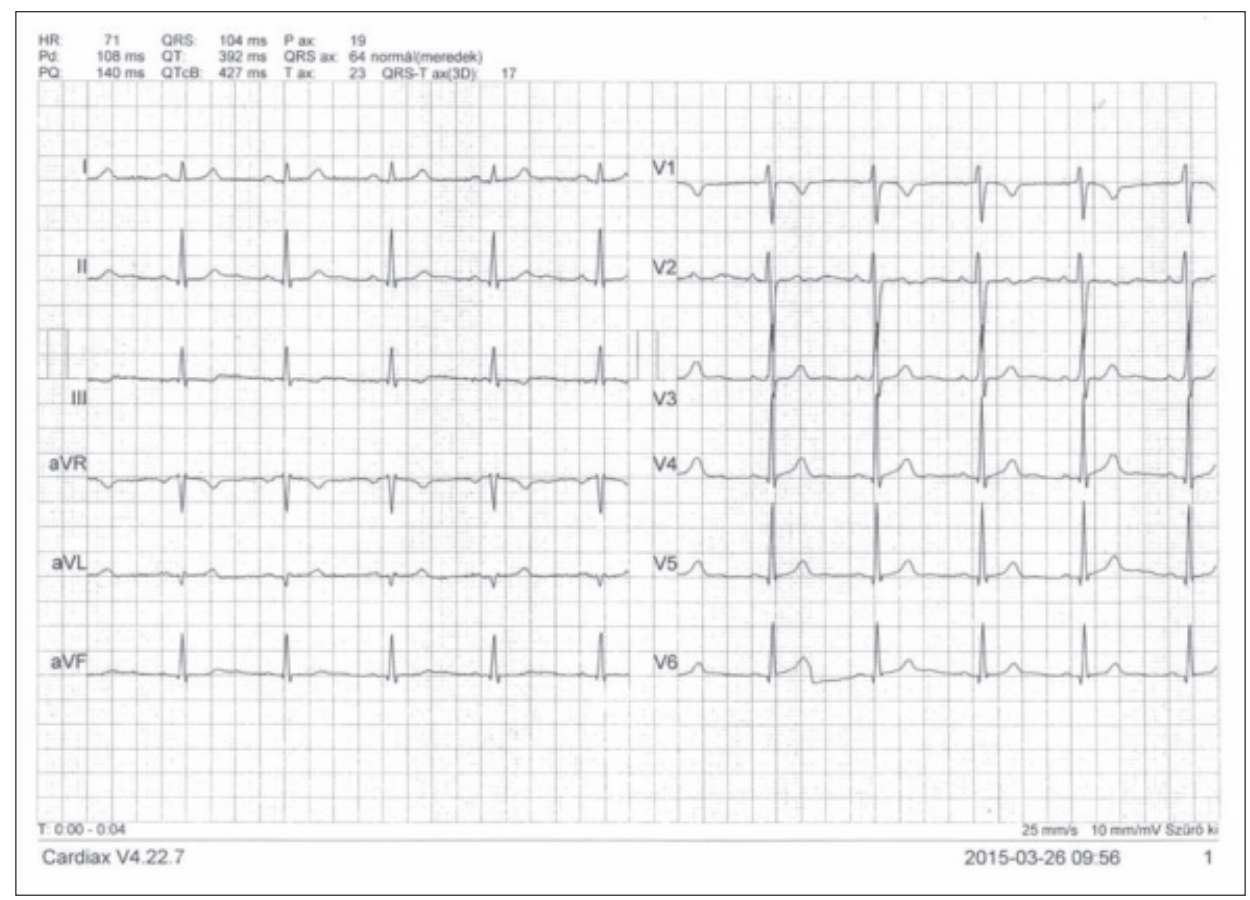

2. ábra. A rohamot követő EKG. Az EKG-n észlelt eltérés a pericarditis gyanúját vetette fel 


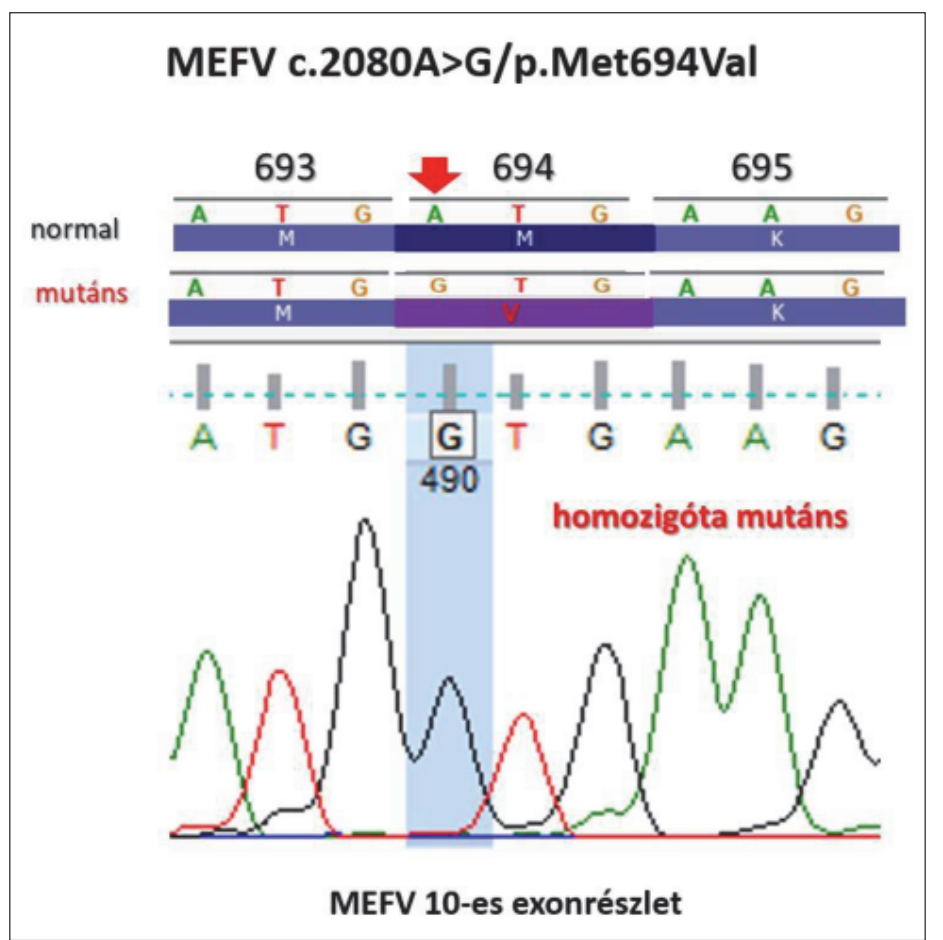

3. ábra. Genetikai vizsgálat: a megvizsgált 31 gén közül 30 génben (ACP5, ADAR, CARD14, DDX58, ELANE, IFIH1, ILIRN, IL36RN, ISG15, LPIN2, MVK, NLRC4, NLRP1, NLRP12, NLRP3, NOD2, PLCG2, PSENEN, PSMB8, PSTPIP1, RNASEH2A, RNASEH2B, RNASEH2C, SAMHD1, SLC29A3, TMEM173. TNFAIP3, TNFRSF1A, TREX1, TRNT1) nem azonosítottunk (pontenciálisan kóroki) mutációt. Az MEFV-génben azonosítottuk egy ismert pathogén aminosavcserét okozó mutációt homozigóta formában, mely felveti a családi mediterrán láz diagnózisát

egy jó indikációval megválasztott genetikai vizsgálat, amely feltehetően költséghatékonyabb is. Úgynevezett génpanelvizsgálatot érdemes kérni, amely az adott fenotípus hátterében álló gének mutációanalízisére alkalmas. Különösen fontosnak tartjuk a genetikai vizsgálatot azokban az esetekben, amikor ma már lehetőségünk nyílik a diagnosztizált kórkép kezelésére. A klinikai genetika sok szakterület munkáját segíti, legfontosabb talán a gyermekgyógyászat és neurológia, de a belgyógyászati szakrendeléstől a szemészeten át a bőrgyógyászati osztályig mindenhol megjelenhet ritka betegségben szenvedő páciens.

Betegünk esetének bemutatása jó példa arra, hogy egy ritka betegség triviálisnak tünő tünetei alapján általában fertőzésre, pszichoszomatikus okra vagy autoimmun betegségre gondolunk. A beteg gyulladásra utaló laboratóriumi eltérései és a splenomegalia szomatikus betegség lehetőségét támogatták, azonban jelentős ellentmondás mutatkozott a teljesen jó állapotú betegnél a fájdalom és a rosszullét intenzitása. A diagnózis ismeretében - utólag értékelve - ez a jel terelhette a gyanúnkat a mediterrán láz irányába. A betegség kezdetének ideje is típusos volt, az inflammatoros periódusok gyermekkorban kezdődtek, a kórtörténetben appendectomia is szerepel.

Az autoinflammatorikus kórképek [1] a ritka monogénes betegségek közé tartoznak, amelyekben immundiszreguláció révén túlzott gyulladás alakul ki bizonyos triggerek hatására aktivizálva a természetes immunitásban

2. táblázat. Autoinflammatorikus gének (a teljesség igénye nélkül) és a hozzájuk kapcsolódó kórképek

\begin{tabular}{llll}
\hline Gén & Lokusz & Fenotípus & Öröklödés \\
\hline CARD14 & $17 \mathrm{q} 25.3$ & Pityriasis rubra pilaris/ Psoriasis 2 & AD \\
IL1RN & $2 \mathrm{q} 14.1$ & Interleukin 1 receptor antagonist deficiency & AR \\
IL36RN & $2 \mathrm{q} 14.1$ & Psoriasis 14, pustular & AR \\
LPIN2 & $18 \mathrm{p} 11.31$ & Majeed syndrome & AD, AR \\
MEFV & $\mathbf{1 6 p 1 3 . 3}$ & Familial Mediterranean fever & AR \\
MVK & $12 \mathrm{q} 24.11$ & Hyper-IgD syndrome / Mevalonic aciduria & AD \\
NLRC4 & $2 \mathrm{p} 22.3$ & $\begin{array}{l}\text { Autoinflammation with infantile enterocolitis / Familial cold autoinflammatory } \\
\text { syndrome 4 }\end{array}$ & \\
\hline
\end{tabular}


2. táblázat. (folyt.)

\begin{tabular}{|c|c|c|c|}
\hline Gén & Lokusz & Fenotípus & Öröklődés \\
\hline NLRP12 & $19 \mathrm{q} 13.42$ & Familial cold autoinflammatory syndrome 2 & $\mathrm{AD}$ \\
\hline NLRP3 & $1 \mathrm{q} 44$ & $\begin{array}{l}\text { CINCA syndrome/ Familial cold-induced inflammatory syndrome } 1 \text { / Muckle-Wells } \\
\text { syndrome }\end{array}$ & $\mathrm{AD}$ \\
\hline NOD2 & $16 \mathrm{q} 12.1$ & Blau syndrome & $\mathrm{AD}$ \\
\hline PLCG2 & $16 \mathrm{q} 23.3$ & $\begin{array}{l}\text { Autoinflammation, antibody deficiency, and immune dysregulation syndrome / Familial } \\
\text { cold autoinflammatory syndrome } 3\end{array}$ & $\mathrm{AD}$ \\
\hline PSMB8 & $6 \mathrm{p} 21.32$ & Autoinflammation, lipodystrophy, and dermatosis syndrome & AR \\
\hline PSTPIP1 & $15 \mathrm{q} 24.3$ & Pyogenic sterile arthritis, pyoderma gangrenosum, and acne & $\mathrm{AD}$ \\
\hline TNFRSF1A & $12 \mathrm{p} 13.31$ & Periodic fever, familial & $\mathrm{AD}$ \\
\hline
\end{tabular}

résztvevő sejteket és molekulákat (2. táblázat). A természetes immunitás a külső és belső veszélyek elleni válaszreakció, amely a citoszolban található úgynevezett „pattern recognition receptor"-okon alapul. Az első ilyen felfedezett receptor az NLRP3 inflammaszoma volt, amelynek mutációi a CAPS (criopyrinasszociált periodikus szindróma) nevü kórképet okozzák. A válasz a kaszpáz-1 mediált IL-1- és IL-18-aktivációval lép fel. Az NLRP3 a criopyrint kódolja, amely más adaptor fehérjékkel (pl. ASC-adapter) az inflammaszomát alkotja. A pyrin éppen ehhez az ASC-adapterhez kötődve tudja gátolni az inflammaszomát, mutációja esetén viszont aktiválódáshoz vezet, és kialakítja az FMF („Familial Mediterranean Fever") kórképét.

Az FMF a leggyakoribb monogénes autoinflammatorikus betegség [2]. Leginkább a mediterrán országokban fordul elő, de bármely populációban megjelenhet. Klinikai tüneteit a savós hártyákon kialakuló periodikusan recidiváló non-infektív gyulladásos folyamatok okozzák (serositis: peritonitis, pleuritis, synovitis, ritkán pericarditis, meningitis). A kórképet először 1945-ben írták le „benignus paroxysmalis peritonitis” néven [3, 4]. Az akutan fellépő peritoneális izgalmi tünetek miatt a betegek laparoscopos mütéteken esnek át [5]. Pericarditisre jellemző EKG-eltérések jelenhetnek meg. Hosszú távú szövődményként amyloidosis alakulhat ki, amely leginkább a vesét veszélyezteti. A betegséget a MEFV-gén mutációi okozzák. A gén a pyrin nevü fehérjét kódolja, amely a komplement 5-ös faktor inhibitora, hiányában komplementaktiváció és komplement mediálta szövetkárosodás alakul ki $[6,7]$. A mutáció miatt az interleukin 1- $\beta$ (IL-1 $\beta$ ) szintje is megemelkedik. Az FMF leginkább autoszomális recesszív módon öröklődik, de autoszomális domináns öröklésmenet is ismert. A betegség kezelésében a colchicin jelenti az első vonalbeli terápiát. A kezelés célja, hogy megelőzzük az akut gyulladásos epizódokat, csökkentsük a krónikus gyulladást, megelőzzük az amyloidozis kialakulását és javítsuk a beteg életminőségét. A colchicinrezisztens vagy -intoleráns beteg esetében szóba jöhet az anti-IL-1-terápia. Irodalmi adat, hogy a heterozygotahordozókban gyakoribb a myeloma multiplex kialakulása [8]. A szakirodalomban nem találtunk említést intravazá- lis haemolízisről e kórképpel kapcsolatban. Érdekes az IgA-hiány társulása is, bár utóbbi a leggyakoribb immunhiányos betegség, amelynek nincs súlyos következménye. Véletlen társulásnak gondoljuk ezt az elváltozást.

A genetikai eredetü betegségek többségében még nem rendelkezünk terápiával, de azoknál a kórképeknél, mint a familiáris mediterrán láz, ahol van elérhető gyógyszer, a genetikai diagnosztika még inkább felértékelődik.

Nyilatkozat: A közlemény más folyóiratban korábban még nem jelent meg, és máshova elküldésre nem került. Levelező szerző a szerzői útmutatót elolvasta.

Érdekeltségek: A szerzőknek nincsenek érdekeltségeik.

Anyagi támogatás: A közlemény megírása anyagi támogatásban nem részesült.

Szerzői munkamegosztás: PH, EM, FJ: Az eset feldolgozása, a cikk megírása. $\mathrm{KJ}$ : Az eset felismerése, a cikk lektorálása. KT, MZ: A molekuláris genetikai vizsgálat elvégzése, diagnózis felvetése. A cikk végleges változatát valamennyi szerző elolvasta és jóváhagyta.

\section{Irodalom}

[1] Montealegre Sanchez GA, De Jesus AA, Goldbach-Mansky R.: Monogenic autoinflammatory diseases: disorders of amplified danger sensing and cytokine dysregulation. Rheum Dis Clin North Am. 2013; 39: 701-734.

[2] De Jesus AA, Goldbach-Mansky R.: Monogenic autoinflammatory diseases: Concept and clinical manifestations. Clin Immunol 2013; 147: 155-174.

[3] Ali Riza O, Ramazan C, Yilmaz S, et al.: Familial Mediterranean fever. South Med J 2002; 95: 1400-1403.

[4] Neda Z, Terri G, Wayne WG, et al.: Diagnosis and management of familial Mediterranean fever: integrating medical genetics in a dedicated interdisciplinary clinic. Genetics in Medicine 2011; 13: 263-269.

[5] Hafize ES, Ezgi DB, Seza Ö: Familial Mediterranean fever: current perspectives. J Inflamm Res 2016; 9: 13-20.

[6] Matzner Y, Abedat S, Shapiro E, et al.: Expression of the familial Mediterranean fever gene and activity of the C5a inhibitor in human primary fibroblast cultures. Blood 2000; 96:727-31.

[7] French FMF Consortium: A candidate gene for familial Mediterranean fever. Nature Genet 1997; 17: 25-31.

[8] Celik S, Erikci AA, Tunca Y, et al.: The rate of MEFV gene mutations in hematolymphoid neoplasms. Int J Immunogenet 2010; 37: $387-391$ 